UDC 36:334.02

http://doi.org/10.21272/mmi.2019.2-04

JEL Classification: F12, L14, M14, Q56

Naira Hakobyan,

D.Sc., Professor, International Scientific-Educational Center of NAS RA, Armenia

Anna Khachatryan,

Ph.D., International Scientific-Educational Center of NAS RA, Armenia

Narine Vardanyan,

Ph.D., Associate Professor, International Scientific-Educational Center of NAS RA, Armenia

Yulija Chortok,

Ph.D., Associate Professor, Sumy State University, Ukraine

Lyudmyla Starchenko,

Ph.D., Associate Professor, Sumy State University, Ukraine

\title{
THE IMPLEMENTATION OF CORPORATE SOCIAL AND ENVIRONMENTAL RESPONSIBILITY PRACTICES INTO COMPETITIVE STRATEGY OF THE COMPANY
}

\begin{abstract}
In modern conditions of the development of globalization processes, any advantages are important for each company in the competitive struggle for the consumer. One of them is the implementation of corporate social and environmental responsibility measures and taking into account its practices in the formation of the company's competitive strategy. The study considers the issue of mechanisms for implementing corporate social and environmental responsibility in companies. The main purpose of the research is to determine corporate social and environmental responsibility role in ensuring the company's competitiveness and to substantiate the methodology of corporate social and environmental responsibility integrated assessment based on the indicators that allow for the needs of stakeholders to be taken into account. It is confirmed that an effective mechanism for corporate social and environmental responsibility implementation by companies is to take into account its practices in the formation of a competitive strategy. The authors analysed the companies' competitiveness indicators that are determined by corporate social and environmental responsibility. It was suggested to use the 4P-complex of corporate social and environmental responsibility for assessing the competitive advantages of the company. It synthesizes such components as follows: People, Planet, Profits and Partnership. These components are characterized by relevant indicators. To assess the effectiveness of implementing the corporate social and environmental responsibility principles into the company's competitive strategy, the authors suggest using the integral corporate social and environmental responsibility index, which synthesizes the assessment of company's corporate social and environmental responsibility by indicators of four components - 4P-complex. The relationship between the integral corporate social and environmental responsibility index and indicators of individual components is proposed to be determined using the geometric average.
\end{abstract}

Keywords: company, competitiveness, components, indicators, corporate social and environmental responsibility, stakeholders, strategy.

Introduction. Corporate social and environmental responsibility (CSER) concept is widespread among European countries. In some countries, CSER is integrated into public policy (Denmark, France, Finland and Sweden); in others, socially responsible practices are exclusively prerogatives of companies (Greece, Ireland, the Netherlands and Slovenia). In the EU, the key role of CSER is to support sustainable development of the company, which leads to the responsible business behaviour, improvement of the situation in the labour market, improvement of the quality of products and services provided by companies, as well as the sustainable development in general (Naslidky, 2012).

Unlike Ukraine, in most European countries, CSER is capable of influencing the competitiveness level of the companies and the state as a whole. Almost all recent studies confirm the impact of CSER on the company's performance. According to (Kavtysh, 2016): «The companies that implement CSER practices are characterized by an increase in sales profitability by $3 \%$, assets - by $4 \%$, and capital and

Cite as: Hakobyan, N., Khachatryan, A., Vardanyan, N., Chortok, Y., \& Starchenko, L. (2019). The Implementation of Corporate Social and Environmental Responsibility Practices into Competitive Strategy of the Company. Marketing and Management of Innovations, 2, 42-51. http://doi.org/10.21272/mmi.2019.2-04 
N. Hakobyan, A. Khachatryan, N. Vardanyan, Y. Chortok, L. Starchenko. The Implementation of Corporate Social and Environmental Responsibility Practices into Competitive Strategy of the Company

shares - by more than $10 \%$. Internal socially responsible activities enhance staff loyalty. This corresponds to the «iron law of responsibility».

The companies can receive the following benefits by carrying out social events: a more attractive image in society; increased trust in companies; increase in turnover, expansion of the list of clients, etc., the improvement of attitude towards companies; appearance of opportunities to receive more favourable orders; appearance of opportunities to reduce local taxes; companies can conduct more active and effective policy in the society through its authority, expanding their activities, including markets, etc.

The issue of the rationality of CSER principles implementation in business practices of Ukrainian companies is beyond doubt. But now, the declarative approach to this issue dominates in the Ukrainian business environment. Despite the fact, that most companies position themselves as socially responsible entities, only very few of them carry out systematic and accurate work in this direction. These are mainly large companies -exporters, representatives of foreign companies and individual service providers. They report on the results and effectiveness of the implemented practices. However, such practices are often just a "fashion brand». Also, the problem is that a number of companies implement such practices, but do not connect them with CSER, does not analyze their impact on the results of company's activities, which also prevents their full use to ensure competitiveness in both national and international markets. In turn, this reduces the competitiveness of industries, regions and the economy as a whole. All this requires raising the issue concerning a comprehensive scientific study of the role and directions of CSER in business activities in order to ensure their strategic competitiveness.

Literature Review. The researchers in their works consider various aspects of the development and implementation of the CSER principles in business activity. Many Ukrainian and foreign scientists devoted their researches to the study of CSER and the mechanisms for its implementation. These are the researches I. Akhnovskaya (Akhnovskaya and Lepikhova, 2016), Ginevicius R. (Ginevicius, 2018), Sukhonos V. (Sukhonos and Makarenko, 2017), etc.

Taking into account our previous studies (Chortok et al., 2018; Yevdokymova et al., 2018), it should be noted that the theoretical developments largely ahead of the real practice of CSER by Ukrainian companies. CSER impact on competitiveness and possibilities for the better cooperation with stakeholders were studied by such domestic scientists as M. Sukhoterina (Filyppova and Sukhoterina, 2015), which offered to diagnosis of conditions and implementation of social responsibility activities in the activity of machine-building companies, E. Tsybulska and M. Kubarieva (Tsybulska and Kubarieva, 2018), M. Saprykina (Saprykina, 2019), T. Vasilieva (Vasilieva et al., 2017), who believed that the increase in business and general social reputation reduces the risk of possible loss of markets, improves access to new markets.

In our research we took into account the scientific works devoted to the study of sustainable development: aspects of green growth of economics (Shkarupa, 2016), tools to ensure market efficiency (Caporale et. al., 2016), ecologic innovations (Kubatko, 2016), economic mechanisms of government support (Hens, 2018), etc.

Researches of S. F. Goncharov and N. A. Krychevskyi (Goncharov et al., 2006) are devoted to the study of methodological approaches to the assessment of CSER, in particular, they proposed a method for assessing the level of corporate social responsibility, which contains both qualitative and quantitative indicators of CSER; T. B. Khlevytska (Khlevytska, 2014), who, suggests combining the concept of a «triple result» with a balanced system of indicators to assess CSER, but this technique does not take into account the external and internal aspects of the company's activities.

A common drawback of the suggested methods is that they do not take into account the opinion of stakeholders while determining the integral assessment of CSER development in the company, which determines the aim of our study. 
N. Hakobyan, A. Khachatryan, N. Vardanyan, Y. Chortok, L. Starchenko. The Implementation of Corporate Social and Environmental Responsibility Practices into Competitive Strategy of the Company

The aim of the article is to determine CSER role in ensuring the company's competitiveness and to substantiate the methodology of CSER integrated assessment based on the indicators that allow for the needs of stakeholders to be taken into account.

Results. According to the results of the International Forum in 2017 (Vplyv, 2017), it is determined that the share of CSER in the reputation of the company is $20 \% .96 \%$ of global top managers believe that the CSER provides added value to the reputation of the company; $80 \%$ of employees consider CSER as an important factor in choosing a company; $91 \%$ of consumers expect CSER projects of the company whose products they buy. However, the study of Ukrainian realities revealed a rather low level of CSER implementation in business.

Thus, according to the (Zinchenko at al., 2018), the average level of disclosure of CSER information on Ukrainian companies' websites in 2017 remained rather low $-21.7 \%$. Only 5 companies from the TOP 100 companies of the country have integrated reporting to achieve the goals of sustainable development in their non-financial reports. Mainly corporate websites have information about the practice of labour relations, development and support of the community and the environment. The issues of providing bonuses to top managers, CSER implementation in the supply chain and responsible marketing policies are the least discussed. As in previous years, most Ukrainian companies do not highlight the results of their CSER activities. They are mainly measured only by companies that prepare reports. Even they do not always provide this information in the relevant sections of the website. International companies have a higher level of CSER disclosure.

Different ranking promotes the increase in the implementation and development of CSER in the company. In the US, for nearly 20 years, the Corporate Responsibility Magazine has been conducted the social responsibility ranking at a rather high level, its data are given in Table 1 (CR, 2018).

The assessment takes place in each of the seven categories (a total of 303 indicators): environment, climate change, labour relations, human rights, corporate governance, finance, philanthropy and community support.

Table 1. TOP-5 leaders in CSER in the USA

\begin{tabular}{|c|c|c|c|c|}
\hline $\mathbf{2 0 1 4}$ & $\mathbf{2 0 1 5}$ & $\mathbf{2 0 1 6}$ & $\mathbf{2 0 1 7}$ & $\mathbf{2 0 1 8}$ \\
\hline $\begin{array}{c}\text { Bristol-Myers } \\
\text { Squibb Co. }\end{array}$ & $\begin{array}{c}\text { Microsoft } \\
\text { Corporation }\end{array}$ & $\begin{array}{c}\text { Microsoft } \\
\text { Corporation }\end{array}$ & Hasbro, Inc. & $\begin{array}{c}\text { Microsoft } \\
\text { Corporation }\end{array}$ \\
\hline Jonson\&Jonson & Hasbro, Inc. & Intel Corp. & Intel Corp. & Accenture plc \\
\hline Gap, Inc. & Jonson\&Jonson & Hasbro, Inc. & $\begin{array}{c}\text { Microsoft } \\
\text { Corporation }\end{array}$ & Owens Corning \\
\hline $\begin{array}{c}\text { Microsoft } \\
\text { Corporation }\end{array}$ & Xerox Corp & Jonson\&Jonson & Altria Group Inc. & Intel Corp. \\
\hline Mattel, Inc. & Sigma-Aldrich Corp & Ecolab. Inc & Campbell Soup Co & Hasbro, Inc. \\
\hline
\end{tabular}

Sources: systematised by the authors on the basis of (CR, 2018).

Social responsibility rankings are also conducted in Ukraine. Since 2011, the CSR Development Centre has been developing the Transparency Index of Ukrainian Companies' Websites on the basis of the international methodology developed by it and Beyond Business (Israel). The results of the ranking are presented in Table 2.

As you can see, for the US companies the CSER has already become a significant competitive advantage, an important factor in the struggle for consumers, a PR-tool, while in Ukraine, the importance of CSER is recognized only by leading companies which want to improve their reputation and get more benefits from CSER implementation. 
N. Hakobyan, A. Khachatryan, N. Vardanyan, Y. Chortok, L. Starchenko. The Implementation of Corporate Social and Environmental Responsibility Practices into Competitive Strategy of the Company

Table 2. TOP-5 leaders of transparency index in Ukraine

\begin{tabular}{|c|c|c|c|c|}
\hline $\mathbf{2 0 1 3}$ & $\mathbf{2 0 1 4}$ & $\mathbf{2 0 1 5}$ & $\mathbf{2 0 1 6}$ & $\mathbf{2 0 1 7}$ \\
\hline DTEK Holding & ArcelorMittal Group & ArcelorMittal Group & ArcelorMittal Group & $\begin{array}{c}\text { PrJSC Myronivsky } \\
\text { Hliboproduct }\end{array}$ \\
\hline ArcelorMittal Group & DTEK & Obolon Corp. & DTEK Holding & DTEK Holding \\
\hline SCM Group & SCM Group & DTEK Holding & SCM Group & $\begin{array}{c}\text { NNEGC } \\
\text { «ENERGOATOM» }\end{array}$ \\
\hline Obolon Corp. & Obolon Corp. & Metinvest Holding & $\begin{array}{c}\text { Concern } \\
\text { Galnaftogaz }\end{array}$ & ArcelorMittal Group \\
\hline Metinvest Holding & Metinvest Holding & Foxtrot & $\begin{array}{c}\text { Naftogaz of Ukraine } \\
\text { NJSC }\end{array}$ & $\begin{array}{c}\text { UKRENERGO NPC } \\
\text { SE }\end{array}$ \\
\hline
\end{tabular}

Sources: systematised by the authors on the basis of (Zinchenko at al., 2018).

We can also note that the majority of Ukrainian companies are still limited by compliance with current legislative requirements within the framework of activities aimed at the lowest and easiest levels of CSER practices in order to obtain only economic benefits (simplifying the tax procedure or reducing the tax base, access to administrative resource, «free» branding, etc.). We believe that this situation is unacceptable in the modern context of CSER practices implementation in the world, including leading international companies, and threatening in a situation where the level of public trust in business and government is falling, threatening the possibility of well-established cooperation with stakeholders and enhancement competitiveness of the company in the market.

To assess the impact of CSER on the competitiveness of the company, consider the example of CSER introduction in a competitive strategy (Figure 1).

Let's consider the competitiveness indicators of companies that determine CSER in more detail:

- The reputation of the company: impact of CSER on reputation has been defined for a long time ago and according to (Saprykina, 2019), the CSER-company's efforts make up 20\% of reputation; $75 \%$ of top managers of global companies consider it necessary to pay attention to social and environmental needs of the society; $90 \%$ of consumers are ready to refuse to buy company products if they find out about their irresponsible practices; $92 \%$ are ready to buy products with social and environmental benefits. That is, CSER helps to build trust between consumers and companies. Moreover, sometimes consumers are even ready to pay more for products of a company with strong CSER practices.

- Partnership: CSER helps to establish relationships with various stakeholders to avoid misunderstandings and conflicts.

- Costs: implementation of CSER measures, such as reduction of the consumption of resources and energy, replacement of equipment, the use of local products instead of import ones make it possible to reduce the costs of operations.

- Brand uniqueness: consumers want to know the features of the CSER of the company they choose. The popularity of environmental measures, such as recycling, greening, social orientation, charity, etc., is not only increasing but has already become an advantage in the competition for the consumer.

- HR-policy: improved corporate culture, better motivation and productivity, the sustainability of staff - all these CSER results contribute to employee engagement in performance increase, improvement of product quality, etc.

- Financial results: above-mentioned indicators help to increase the company's income, reduce the costs and thus increase efficiency as a whole. 
N. Hakobyan, A. Khachatryan, N. Vardanyan, Y. Chortok, L. Starchenko. The Implementation of Corporate Social and Environmental Responsibility Practices into Competitive Strategy of the Company

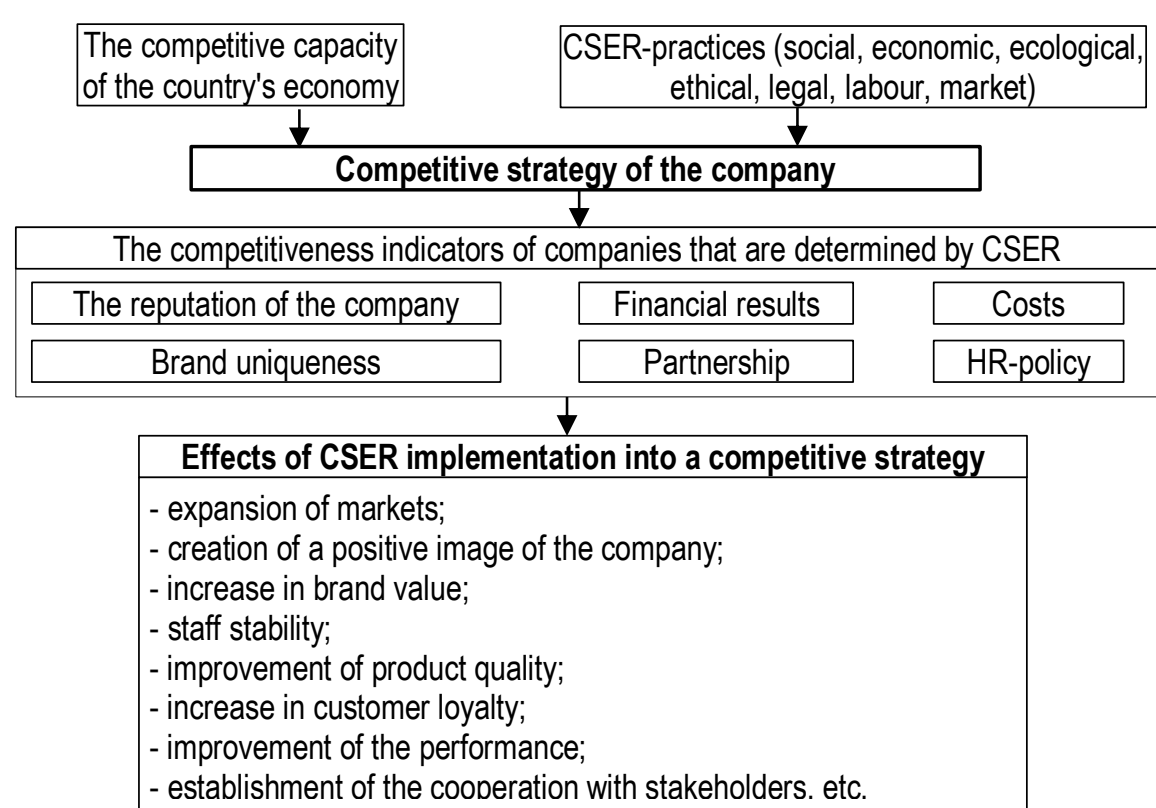

Figure 1. The impact of CSER on the competitiveness of the company as a result of CSER-practices introduction in a competitive strategy

Sources: developed by the authors on the basis of (Kavtysh, 2016).

Indeed, if you define competitiveness, a key management task, to be such one that consists in the selection and implementation of competitive strategy, it can be noted that CSER stimulates its immediate implementation. Moreover, implementation of CSER into a competitive strategy will not only provide the growth of the companies themselves but also lead to a synergistic effect of the environment of their operation (from the chain of companies' values to the implementation of the territories' values, industries, economy). In order to develop an effective competitive strategy taking into account social and environmental responsibility, the management of the company needs to identify a list of its specific social and environmental problems. It is also worthwhile to define the circle of stakeholder since they can support the company's socio-environmental initiatives at any stage and help to uncover new prospects for business development. It should not be forgotten about continuous monitoring, evaluation of the CSER level and reporting of the company. The latter serves as an effective means of communicating with society, a precondition for access to international capital markets and it promotes staff development and the promotion of goods and services. According to Tsybulska (Tsybulska et al., 2018) in the development of tools increasing the strategic competitive advantages of the industrial enterprises of the position of socially responsible activities is advisable to draw on the ideas of John Elkington, who introduced the concept of triple up of the corporation, which includes financial and ecological measurements, appropriate eco-efficiency ideas within corporate sustainability. Three strengths Elkington marked as 3P (People, Planet, Profits). We have proposed to assess the competitive advantages of using 4P-complex of CSER (Figure 2), which synthesizes such components as People, Planet, Profits and Partnership. 
N. Hakobyan, A. Khachatryan, N. Vardanyan, Y. Chortok, L. Starchenko. The Implementation of Corporate Social and Environmental Responsibility Practices into Competitive Strategy of the Company

\begin{tabular}{|c|c|c|c|}
\hline $\begin{array}{l}\text { PROFIT } \\
\text { - company value } \\
\text { - quality and price of products } \\
\text { - sell-through crowd-shipping } \\
\text { - use innovative vehicle technologies and } \\
\text { tires } \\
\text { - smart and green building deployments } \\
\text { - reduce travel distance }\end{array}$ & $\begin{array}{l}0 \\
0 \\
0 \\
0\end{array}$ & $\begin{array}{l}\text { - impro } \\
\text { - share } \\
\text { - use of } \\
\text { and cor } \\
\text { - source } \\
\text { - consic } \\
\text { network }\end{array}$ & $\begin{array}{l}\text { PARTNERSHIP } \\
\text { upply chain visibility } \\
\text { vork facilities and transport } \\
\text { re sustainable raw materials } \\
\text { nents } \\
\text { m local suppliers } \\
\text { nore decentralized distribution }\end{array}$ \\
\hline Certain/short term & \multicolumn{2}{|c|}{$\begin{array}{l}\text { COMPETITIVENESS OF } \\
\text { THE COMPANY }\end{array}$} & Less certain/long term \\
\hline $\begin{array}{l}\text { PEOPLE } \\
\text { - working conditions } \\
\text { - implement far wages policy and empower } \\
\text { the workforce } \\
\text { - enforce high environment health, safety } \\
\text { standards } \\
\text { - education, career growth }\end{array}$ & & $\begin{array}{l}\text { - recycl } \\
\text { - produc } \\
\text { - energ } \\
\text { - waste } \\
\text { - use al } \\
\text { - use m }\end{array}$ & $\begin{array}{l}\text { PLANET } \\
\text { ty and circularity } \\
\text { footprint } \\
\text { ater use and emissions } \\
\text { nagement } \\
\text { ative fuels } \\
\text { sustainable transport }\end{array}$ \\
\hline
\end{tabular}

Figure 2. Components of 4P-complex of CSER, influencing the competitiveness of the company Sources: developed by the authors.

These four components are formed according to 17 new Sustainable Development Goals ('SDGs'), adopted in 2015 to make our world more prosperous, inclusive, sustainable and resilient. They are universal, applying to all nations and people, wide-ranging including ending poverty and hunger, ensuring sustainable consumption and production, etc. Each and every SDG provides an opportunity for business. Let's consider them more detailed:

- The partnership means «stakeholder engagement - a constructive dialogue for the information exchange between the company and the stakeholders on CSER initiatives. In a seminal paper on stakeholder theory» (Freeman, 1984). Freeman defines a stakeholder as: «any group or individual who can affect or is affected by the achievement of an organization's purpose». He distinguishes such stakeholder groups: customers, shareholders, employees, suppliers and community groups/NGOs. Stakeholder cooperation can be realized by various methods, in particular through the publication of CSR reports, focus groups, briefings, public meetings and internal reports. It should be noted that the lead companies are ready for the constant involvement of a wide range of stakeholders in the design and implementation of CSR measures that can become the basis for their reporting.

For example, an important element of implementing CSER is the establishment of such cooperation with suppliers that would contribute to the achievement of social, ethical and environmental compliance from them: using of conduct codes that cover operations and demand compliance with an extensive set of labour, health and safety, and environmental standards. It also means the existence of mechanisms for tracking compliance with ethical sourcing/purchasing policies, greenhouse management programs, supplier engagement in educational programs on labour rights, CSER reporting, and joint creation of sustainable products.

- Planet: is connected with «environmental performance». It means all policies, practices, ecofriendly initiatives, providing by the company for reducing energy, water and paper consumption, reducing greenhouse gas emissions, and implementation of material usage reduction programs. ISO 140001 certifications are associated with a positive market reaction.

- People: is connected with community, employees and consumers. Many scientists, whom we have mentioned above, find evidence for the positive link between community investments and financial 
N. Hakobyan, A. Khachatryan, N. Vardanyan, Y. Chortok, L. Starchenko. The Implementation of Corporate Social and Environmental Responsibility Practices into Competitive Strategy of the Company

returns. They suggest that good community relations can help a firm obtain a competitive advantage through tax benefits, a decreased regulatory burden, and improvement in the quality of local labour.

- Profit: CSER implementation in the practice of the company stimulates the additional profits generation by increasing the number of consumers, increasing the effectiveness of cooperation with stakeholders, etc. The disadvantage is that these effects only manifest in the long run and it is difficult to determine which factors have played a major role in achieving such results.

To assess the effectiveness of CSER principles implementation in the competitive strategy of the company, we have proposed to use the integral index of CSER (ICSER), which synthesizes the CSER evaluation of the company by the indicators of 4P-complex components (Table 3 ).

Table 3. Indicators of 4P-complex components

\begin{tabular}{|c|c|c|}
\hline Component & Index & Indicators \\
\hline Profit & $\begin{array}{l}\text { Economic Development } \\
\text { Index } \\
I_{\text {profit }}\end{array}$ & $\begin{array}{ll}- & \text { company value } \\
- & \text { quality and price of products } \\
- & \text { sales of goods and services } \\
- & \text { payments to shareholders } \\
- & \text { investments, etc. }\end{array}$ \\
\hline Partnership & $\begin{array}{l}\text { Index of cooperation } \\
\text { with stakeholders } \\
I_{\text {partnership }}\end{array}$ & $\begin{array}{ll}- & \text { taxes } \\
- & \text { legality of doing business } \\
- & \text { corruption perceptions level } \\
- & \text { cooperation agreements with local authorities, NGOs } \\
- & \text { community initiatives support }\end{array}$ \\
\hline People & $\begin{array}{l}\text { Social Development } \\
\text { Index } \\
\text { Ipeople }\end{array}$ & $\begin{array}{ll}- & \text { number of employees } \\
- & \text { the number of additional jobs created } \\
- & \text { costs for social activities, cultural, sports activities } \\
- & \text { financial aid, gifts } \\
- & \text { the cost of labour protection } \\
- & \text { the level of ensuring gender equality, etc. } \\
\end{array}$ \\
\hline Planet & $\begin{array}{l}\text { Ecological Development } \\
\text { Index } \\
\text { Iplanet }\end{array}$ & $\begin{array}{ll}- & \text { the cost of implementing environmental programs } \\
- & \text { share of recycled materials using } \\
- & \text { emissions } \\
- & \text { wastes } \\
- & \text { ecological investments, etc. }\end{array}$ \\
\hline
\end{tabular}

Sources: developed by the authors.

The relationship between the integral CSER-index and the individual components indexes is represented by the formula:

$$
\begin{aligned}
& I_{\text {CSER }}=\sqrt[4]{I_{\text {profit }} * I_{\text {partnership }} * I_{\text {people }} * I_{\text {planet }}} \\
& I_{\text {profit }}=\sqrt[n]{\prod_{i=1}^{n} I_{i}} \\
& I_{\text {partnership }}=\sqrt[m]{\prod_{j=1}^{m} I_{j}}
\end{aligned}
$$




$$
\begin{aligned}
& I_{\text {people }}=\sqrt[l]{\prod_{k=1}^{l} I_{k}} \\
& I_{\text {planet }}=\sqrt[r]{\prod_{t=1}^{r} I_{t}}
\end{aligned}
$$

where $l_{i}$ - index changes of profit component indicator, $n$ - amount of profit component indicators; $l_{j}$ - index changes of partnership component indicator, $m$ - amount of partnership component indicators; $I_{k}$ - index changes of people component indicator, $I$ - amount of people component indicators; $I_{t}-$ index changes of planet component indicator, I - amount of planet component indicators.

Conclusions. Thus, it should be concluded that the practice of forming a culture of socially responsible business has been widespread in Ukraine recently. The state creates conditions and promotes the development of its own public position on the corporate social responsibility of companies. In particular, for companies, the most significant issues were fair conduct in the market and environmental safety. The implementation of a customer-oriented policy is also important. Much is being done to identify the «best practices» of socially oriented companies. In our opinion, CSER is a factor that can significantly influence the global economic efficiency of the company. However, this can be achieved only under the condition of constant economic activity in the field of social responsibility and if companies pay enough attention to the requirements of stakeholders. The list of benefits that companies receive from CSER programs usually includes the following: risk reduction, waste reduction, improving relations with regulatory authorities, education and brand support, improvement of human relations and employee productivity, reduction in the cost of capital. The review of the special features of the CSER business in Ukraine allows concluding the following:

1. Social responsibility of business arises as an objective need of the companies themselves, which seek to find their place in the competitive environment, their consumers and seek to attract the interest of Ukrainian and international partners and highly qualified specialists.

2. The business need for CSER is formed under the influence of the mentality of the population and strengthening of globalization trends.

3. Ukrainian companies face a problem of creating an effective competitiveness management system, which is a decisive one in the formation of performance results.

4. CSER plays an extremely important role in shaping and building relations system with public and stakeholders as a PR tool and as an indicator of responsible partnership, respectively.

Author Contributions: Conceptualization, Y. C. and N. H.; methodology, A. K.; validation, N. H., Y. C. and N. V.; formal analysis, A. K.; investigation, A. K.; resources, A. K.; data curation, Y. C.; writingoriginal draft preparation, Y. C.; writing-review and editing, Y. C.; visualization, N. H.; supervision, A. K.; funding acquisition, N. V.

Funding: This research was funded by the Grant from the Ministry of Education and Science of Ukraine (No of state registration 0117U003933) «Corporate social and environmental responsibility for sustainable development: stakeholder's partnership in the real, financial and public sectors of the economy».

\section{References}

Akhnovskaya, I., \& Lepikhova, O. (2016) Mekhanizm vprovadzhennia korporatyvnoi sotsialnoi vidpovidalnosti na pidpryiemstvakh Ukrainy [Mechanism of implementation of corporate social responsibility for Ukrainian enterprises] Ekonomika $i$ orhanizatsiia upravlinnia - Economics and Management Organization, 1(21), 37-44. Retrieved from http://jeou.donnu.edu.ua/article/view/2368_[in Ukrainian]. 
N. Hakobyan, A. Khachatryan, N. Vardanyan, Y. Chortok, L. Starchenko. The Implementation of Corporate Social and Environmental Responsibility Practices into Competitive Strategy of the Company 9484-9

Caporale, G.M., Gil-Alana, L., Plastun, A. et al. Comput Econ (2016) 47: 275. https://doi.org/10.1007/s10614-015-

Chortok, Yulija; Yevdokymova, Alona; Serpeninova, Yuliya. Formation of the Mechanism of Corporate Social and Environmental Responsibility of the Trading Company. Journal of Environmental Management and Tourism, [S.I.], v. 9, n. 5, p. 1011-1018.DOI: https://doi.org/10.14505//jemt.9.5(29).13.

CR Magazine's 100 Best Corporate Citizens (2018). Retrieved from: https://www.3blassociation.com/corporate-responsibilitymagazine/100-best-corporate-citizens

Filyppova, S. V., Sukhoterina, M. I. (2015) Porivnialna kharakterystyka metodyk otsinky efektyvnosti systemy korporatyvnoi sotsialnoi vidpovidalnosti mashynobudivnoho pidpryiemstva [Comparative characteristics of methods for assessing the effectiveness of corporate social responsibility system at the machine-building enterprise]. Biznesinform - Businessinform, 3 284287. Retrieved from: http://www.business-inform.net/export_pdf/business-inform-2015-3_0-pages-284_287.pdf_in Ukrainian]

Freeman, R.E. (1984) Strategic Management: A Stakeholder Approach; Cambridge University Press: Cambridge, UK, p. 53.

Ginevicius, R., Gedvilaitè, D., Stasiukynas, A., Cepel, M. (2018). Integrated Assessment of the Socioeconomic Systems' Development. Economics and Sociology, Vol. 11(1), pp. 11-21. http://doi.org/10.14254/2071-789X.2018/11-1/1

Hens, L., Karintseva, O., Kharchenko, M., \& Matsenko, O. (2018). The state's structural policy innovations influenced by the ecological transformations. Marketing and Management of Innovations, 3: 290-301. http://doi.org/10.21272/mmi.2018.3-26.

Honcharov, S.F. (2006) Korporatyvnaia sotsyalnaia otvetstvennost [Corporate Social Responsibility]. Moscow, Dashkov \&Ko. [in Russian]

Kavtysh, O.P., Prokopenko ,Ya.H. (2016) Rol KSV u zabezpechenni konkurentospromozhnosti natsionalnykh pidpryiemstv [The role of CSR in ensuring the competitiveness of national enterprises]. Suchasni problemy ekonomiky i pidpryiemnytstvo Modern Problems of Economics and Business. 18, 128-136 [in Ukrainian]

Khlevytska, T. B. (2014) Methodical approach to the assessment of corporate social activities effectiveness at the enterprises on the integrative platform [Metodychnyi pidkhid do otsinky efektyvnosti korporatyvnoi sotsialnoi diialnosti pidpryiemstv na intehratyvnii platformi]. Economic Development Strategy for Ukraine - Stratehiia ekonomichnoho rozvytku Ukrainy, 34, 135-141. Retrieved from: https://core.ac.uk/download/pdf/32608439.pdf [in Ukrainian]

Kubatko, O. (2016). Ecological innovations as a source of fluctuations of national economy energy efficient development. Marketing and Management of Innovations, 4: 365-376.

Makarenko I. A., Vasilieva T. A., Lieonov S. V., Sirkovska N. (2017) Sustainability information disclosure as an instrument of marketing communication with stakeholders: markets, social and economic aspects. Marketing and Management of Innovations, №4, 350-357. http://doi.org/10.21272/mmi.2017.4-31

Naslidky nepryiniattia natsionalnoi polityky z korporatyvnoi sotsialnoi vidpovidalnosti (KSV) dlia Ukrainy [The consequences of national policy rejection on corporate social responsibility (CSR) for Ukraine] (2012). Retrieved from:http://csr-ua.info/csrukraine/wp-content/uploads/2013/11/cost_of_non_adoption_final.pdf [in Ukrainian]

Saprykina, M. (2019) CSR and competitiveness of companies - KSV i konkurentospromozhnist kompanii. Retrieved from: http://csr-ua.info/csr-ukraine/article/ксв-і-конкурентоспроможність-компан/ [in Ukrainian]

Shkarupa, O.V., Karintseva, O.I., Shkarupa, I.S. (2016) Innovation Potential of Ecological Modernization for Green Growth of Economics: A Case Study". International Journal of Ecology \& Development, 1(31), 73-82. Retrieved from: http://www.ceser.in/ceserp/index.php/ijed/article/view/4044,

Sotnyk, I., Shvets, I., Momotiuk, L., \& Chortok, Y. (2018). Management of Renewable Energy Innovative Development in Ukrainian Households: Problems of Financial Support. Marketing and Management of Innovations, 4, 150-160. http://doi.org/10.21272/mmi.2018.4-14

Tsybulska, E.I. \& Kubarieva, M. V. (2018) Otsinka stratehichnykh konkurentnykh perevah kompanii na osnovi korporatyvno sotsialnoi vidpovidalnosti [An assessment of the strategic competitive advantages of the company on the basis of corporate social responsibility]. Naukovyi visnyk Uzhhorodskoho natsionalnoho universytetu - Scientific Bulletin of the Uzhgorod National University, 19 (3), 128-132. Retrieved from: http://www.visnyk-econom.uzhnu.uz.ua/archive/19_3_2018ua/29.pdf] [in Ukrainian]

Victor Sukhonos and Inna Makarenko (2017). Sustainability reporting in the light of corporate social responsibility development: economic and legal issues. Problems and Perspectives in Management, 15(1-1), 166-174. doi:10.21511/ppm.15(11).2017.03

Vplyv korporatyvnoi sotsialnoi vidpovidalnosti na biznes-pokaznyky obhovoriuvaly uchasnyky mizhnarodnoho forumu u Lutsku - Impact of corporate social responsibility for business indicators discussed the participants of the international forum in Lutsk (2017). Retrieved from: http://csr-ua.info/csr-ukraine/article/вплив-корпоративної-соціальної-відп/[ [in Ukrainian]

Zinchenko, A., Reznik, N., Saprykina, M. (2018) Indeks prozorosti saitiv ukrainskykh - 2017 [Transparency Index of Ukrainian Companies Sites - 2017]. Kyiv: Yuston [in Ukrainian]. 
N. Hakobyan, A. Khachatryan, N. Vardanyan, Y. Chortok, L. Starchenko. The Implementation of Corporate Social and Environmental Responsibility Practices into Competitive Strategy of the Company

Наїра Акопян, D.Sc., Міжнародний науково-освітній центр НАН РВ (Вірменія);

Анна Хачатрян, Ph.D., Міжнародний науково-освітній центр НАН РВ (Вірменія);

Наріне Варданян, Ph.D., доцент, Міжнародний науково-освітньоій центр НАН РВ (Вірменія);

Юлія Чорток, к.е.н., доцент, Сумський державний університет (Украӥна);

Людмила Старченко, к.е.н., доцент, Сумський державний університет (Україна).

Впровадження практик корпоративної соціально-екологічної відповідальності у конкурентну стратегію компанії

В сучасних умовах розвитку глобалізаційних процесів для кожної компанії в конкурентній боротьбі за споживача є важливими будь-які переваги. Однією з них стає впровадження заходів корпоративної соціально-екологічної відповідальності та врахування ії практик при формуванні конкурентної стратегії компанії. У статті підлягають розгляду питання щодо механізмів реалізації корпоративної соціально-екологічної відповідальності компаніями. Доведено, що ефективним механізмом впровадження корпоративної соціально-екологічної відповідальності компаніями є врахування її практик при фоормванні конкурентної стратегії, наведено ефекти впровадження корпоративної соціально-екологічної відповідальності у конкурентну стратеаію. Основною метою дослідження стало визначення ролі корпоративної соціальної та екологічної відповідальності у забезпеченні конкурентоспроможності компанії та обірунтування методології інтегрованої оцінки корпоративної соціальної та екологічної відповідальності на основі показників, що дозволяють враховувати потреби зацікавлених сторін. Підтверджено, що ефективним механізмом реалізації корпоративної соціальної та екологічної відповідальності підприємства $\epsilon$ врахування його практики у фоормуванні конкурентної стратегії. Авторами проаналізовані показники конкурентоспроможності компаній, які визначає корпоративна соціально-екологічна відповідальність. Для оцінки конкурентних переваг компанії запропоновано використовувати 4Pкомплекс корпоративної соиіально-екологічної відповідальності, який синтезує в собі такі компоненти як Люди, Планета, Доходи та Партнерство. За цими компонентами наведені відповідні індикатори. Для оцінки ефективності впровадження принципів корпоративної соціальноекологічної відповідальності у конкурентну стратегію компанії авторами пропонується використовувати інтегральний індекс корпоративної соціально-екологічної відповідальності (ІІсЕR), який синтезує в собі оцінку корпоративної соціально-екологічної відповідальності компанії за показниками чотирьох компонент 4Р-комплексу. Взаємозв'язок між інтегральним індексом корпоративної соціально-екологічної відповідальності та індексами окремих компонент пропонується визначати за допомогою середньої геометричної.

Ключові слова: компанія, компонента, конкурентоспроможність, корпоративна соціально-екологічна відповідальність, показник, стейкхолдер, стратегія.

Manuscript received: 07.02.2019.

(C) The author(s) 2019. This article is published with open access at Sumy State University. 